\title{
Effect Analysis of Real Estate Price and Monetary Policy: An Empirical Study Based on China Macroeconomic Data
}

\author{
Liang $\mathrm{Su}^{1}, \mathrm{Li} \mathrm{Lin}^{1}$, Shaozhen Chen ${ }^{1}$, Lin $\mathrm{Li}^{2}$ \\ ${ }^{1}$ Finance Department of International Business School, Jinan University, China \\ ${ }^{2}$ School of Translation Studies, Jinan University, China \\ Correspondence: Liang Su, Finance Department of International Business School, Jinan University, China.
}

Received: January 17, 2018

Accepted: February 15, 2018 Available online: February 27, 2018

doi:10.11114/aef.v5i2.2930

URL: https://doi.org/10.11114/aef.v5i2.2930

\begin{abstract}
Since the reform of the housing system in 1998, China's real estate market has been gradually marketized. A large number of demand-side purchases that were suppressed by the planned economy were released. The rapidly rising real estate prices affected the People's Bank of China's monetary policy through Tobin's Q and the financial accelerator. This paper establishes a VAR model to analyze the policy factors and find out "land finance" has promoted the rise of real estate prices to a certain extent and the regulation of the real estate market lags behind; real estate prices can interfere with the effect of monetary policy which rising real estate prices increase the uncertainty of monetary policy. Finally, this paper puts forward policy suggestions of the monetary policy and local fiscal revenue.
\end{abstract}

Keywords: monetary policy, real estate price, VAR, land finance

\section{Introduction}

Since 1998, the housing reform in China has gradually established and improved the market price mechanism. Between 2005 and 2017, the average prices of real estate transaction in the country grew at a rate of nearly $10 \%$ a year, and house prices in regions such as Beijing and Shanghai far outpaced those in other cities. Previously, real estate prices are subject to the housing rationing system. It cannot well reflect the market supply and demand. Housing system reform will marketize the real estate prices. On the one hand, it helps the market to reflect the real estate supply and demand reasonably; on the other hand, it will also release the long-suppressed demand. Since the reform and opening up, the disposable income of Chinese households has risen, further pushing up the real estate prices. In addition, the continuous expansion of the fiscal deficit is also an important factor in real estate prices rising.

In the 1990s, the State Council decided to carry out tax-sharing reform and further divide the financial and administrative powers of the central and local governments. For local governments, this means a decrease in fiscal revenue while at the same time requiring more government responsibilities and increasing local fiscal burdens. Large government deficits and declining revenues have also forced local governments to raise money through land transfers. This kind of financial fund-raising method is also called "land finance" because it obtains financial support by transferring the right to the state-owned land. Local governments can get the land transfer fees and land tax revenue. At the same time, the development of the real estate industry will also lead to local economic growth, thereby enhancing the government's performance. Local governments have the inherent motivation to obtain financial support through "land finance", which is the main reason for the rising cost of land for real estate development.

After years of development, the real estate industry has become a pillar industry in many local economies. It is already a common method for the government to promote the development of local economy by developing the local real estate industry through proactive policies and reusing real estate investments to drive the development of other related industries. However, the continued expansions of real estate investment scale and rising real estate prices also have many adverse effects. From the perspective of capital flow, the fiery real estate market has attracted a lot of money into the real estate market, while investing in the real estate market requires a long period of capital recovery. Too much capital which flows to the real estate market will take up investment in other real economies. To a certain extent, it will also hinder the development of the real economy. On the other hand, the price of real estate will also interfere with the effect of monetary policy. The rising of real estate prices will increase the cost of social financing, leading to more and more financing difficulties in other industries. According to Bernanke's theory of financial accelerators, because of the 
difficulty of financing and the deteriorating balance sheet, banks will reduce the solvency scale of enterprises and further reduce the source of funds for enterprises. The inter-company loan creates the domino effect in the social economy. At the macro level, the central bank will inevitably regulate and control asset prices, thereby disrupting the realization of the ultimate goal of monetary policy. Scholars have conducted extensive discussions on the relationship between monetary policy and asset prices.

Based on the VAR model proposed by Sims, we establish an empirical model about the transmission of monetary policy and real estate prices. According to the real estate price changes and the monetary policy data from 2005 to 2017 in China, we analyze the interference of the local government's financing mode on the monetary policy in terms of the real estate price's impact on the monetary policy intermediate index. The structure of this paper is as follows: In the first part, the paper reviews and summarizes the relevant literature on the causes of rising house prices and the selection of intermediary targets for monetary policy. The second part introduces the VAR model in this paper. The third part is the empirical research. The inter-relationship and its size of the variables are analyzed step by step based on the VAR model. The fourth part summarizes the research results of this article and makes suggestions on policy accordingly.

\section{Literature Review}

\subsection{The Relationship between Land Price and Real Estate Price}

Foreign research on real estate prices started earlier, and the relevant theoretical research is better than that of China. Muth (1960), Huang (1966) and Smith (1969) constructed the first generation real estate price model from the perspective of demand in order to study the real demand of the real estate market as well as the impact of rent and use cost on real estate prices. Kearl (1979), Buckley and Ermisch (1982), Dougherty and van Order (1982) and Poterba (1984) considered both investment demand and taxation and enriched the demand factors further thereby forming the second generation real estate prices model. Summer (1981), Poterba (1991) and Madsen (2011) innovated on the basis of Tobin's Q Theory and set up the relationship between housing investment and the cost of housing construction. Then they proposed a new real estate price theory and model.

Compared with the changes in real estate prices abroad, there is a large speculative component in China's real estate market, leading to the fact that foreign scholars' research results cannot be used to explain China's real estate price changes. Focusing on the special situation in China, many domestic scholars put forward their own views. Wang Ju (2008) analyzed the changes in the fiscal revenue and expenditure of local governments after the tax-sharing reform and considered that the local governments raised financial funds by over-using the "land finance" in order to alleviate the financial difficulties and thus boosted the real estate prices. Zhou Bin and Du Liangsheng (2010) found by building a general equilibrium model that the "land finance" is the factor that drives the continuous rise in house prices. The rise of house prices has increased the utility of the government and the government has the intrinsic motivations to promote house prices.

\subsection{Real Estate Price and the Monetary Policy Intermediary Index}

The traditional theoretical view holds that there are many channels that allow asset prices to affect the real economy, such as the Wealth Effect Theory proposed by Friedman (1957), Tobin's Q Theory (1969), and the "Financial Accelerator" Effect (1989). Because asset prices have an impact on the real economy, the central bank usually focuses on changes in asset prices. Borio and Lowe (2002) emphasized that monetary policy should not only focus on inflation. Ahearne (2005) believes that the preemptive reaction of monetary policy toward asset prices is good for controlling the crisis in the real economy. Leamer (2007) studied the real estate market in the United States and found that real estate investment contributes $26 \%$ to the economy. The implementation of the stimulus monetary policy by the Federal Reserve will prosper the real estate market. On the contrary, Bernanke (1999) argues that if the central bank reacts directly to the asset price changes by adjusting interest rate, the economic fluctuations will be aggravated. As for the question whether the central bank's monetary policy responds to changes in asset prices, scholars have conducted an empirical study. Bjornland and Jacobsen (2009) analyzed the real estate market in Britain, Sweden, and Norway data. They found that a country's real estate price changes will affect the local interest rate level, and the rise of the real estate price will cause the rising real interest rate of the country.

In China, since the late 1990s, many scholars have made effort to find out whether the domestic asset price can be used as an intermediate indicator of monetary policy. Zhai Qiang (2001) argues that the central bank may use asset prices as an indirect reference during operation of the monetary policy, but not directly as an intermediate indicator of monetary policy. However, Yi Gang and Wang Zhao (2002) argue that the central bank should take the stock market price into consideration while making monetary policy. It should also regard the asset price as an auxiliary measure in monetary policy control. It should be observed by the central bank. Chen Shiyi and Wang Xiang (2016) set up a multi-sectoral DSGE model. At the same time, they introduced the real estate market and the banking sector with financial friction to study the transmission mechanism in which monetary policy affects real estate prices. Their conclusion shows that the 
central bank's monetary policies focus on real estate price fluctuations. It can improve social welfare to a certain extent, but it will result in an increased cost of social financing and a decrease in the effects of policies.

\section{Vector Autoregressive Model}

Christopher A. Sims founded and developed a vector autoregressive model in the 1980s, which can solve the problem of variable identification in an empirical study. In VAR model, each variable takes lag variables as explanatory variables to form a model system of multivariate simultaneous equations. VAR model can well reflect the dynamic effects and hysteretic characteristics of endogenous variables. There are some methods based on VAR model can be used to analyze the dynamic relationship between variables, including multivariate Granger causality test, impulse-response analysis, and variance decomposition. They can also describe and forecast the macroeconomic variables, having become important methods in economic policy analysis.

The VAR model also has some shortcomings, which are criticized by many scholars. For example, the traditional VAR model is easily affected by the order of the variables and the reliability of the analysis results is reduced. Despite its deficiencies, the easily understood process of the VAR model still makes it an important tool for macroeconomic analysis. At the same time, model sensitivity can be analyzed iteratively in index order to avoid analysis discrepancies caused by variable order.

Based on the analysis of the relationship between land finance and monetary policy, this paper establishes a quaternary VAR (n) model, regarding real estate prices, interest rates, money supply and land prices as analysis variables. The specific expressions are,

$$
\begin{gathered}
\left(\begin{array}{c}
H P_{t} \\
R_{t} \\
M_{t} \\
L P_{t}
\end{array}\right)=\left(\begin{array}{l}
d_{1} \\
d_{2} \\
d_{3} \\
d_{4}
\end{array}\right)+\left(\begin{array}{llll}
\alpha_{11} & \beta_{11} & \gamma_{11} & \eta_{11} \\
\alpha_{21} & \beta_{21} & \gamma_{21} & \eta_{21} \\
\alpha_{31} & \beta_{31} & \gamma_{31} & \eta_{31} \\
\alpha_{41} & \beta_{41} & \gamma_{41} & \eta_{41}
\end{array}\right)\left(\begin{array}{c}
H P_{t-1} \\
R_{t-1} \\
M_{t-1} \\
L P_{t-1}
\end{array}\right)+\left(\begin{array}{llll}
\alpha_{12} & \beta_{12} & \gamma_{12} & \eta_{12} \\
\alpha_{22} & \beta_{22} & \gamma_{22} & \eta_{22} \\
\alpha_{32} & \beta_{32} & \gamma_{32} & \eta_{32} \\
\alpha_{42} & \beta_{42} & \gamma_{42} & \eta_{42}
\end{array}\right)\left(\begin{array}{c}
H P_{t-2} \\
R_{t-2} \\
M_{t-2} \\
L P_{t-2}
\end{array}\right)+ \\
\ldots+\left(\begin{array}{llll}
\alpha_{1 n} & \beta_{1 n} & \gamma_{1 n} & \eta_{1 n} \\
\alpha_{2 n} & \beta_{2 n} & \gamma_{2 n} & \eta_{2 n} \\
\alpha_{3 n} & \beta_{3 n} & \gamma_{3 n} & \eta_{3 n} \\
\alpha_{4 n} & \beta_{4 n} & \gamma_{4 n} & \eta_{4 n}
\end{array}\right)\left(\begin{array}{c}
H P_{t-n} \\
R_{t-n} \\
M_{t-n} \\
L P_{t-n}
\end{array}\right)+\left(\begin{array}{c}
\varepsilon_{1 t} \\
\varepsilon_{2 t} \\
\varepsilon_{3 t} \\
\varepsilon_{4 t}
\end{array}\right) .
\end{gathered}
$$

Sims assumes that $\varepsilon_{k t}(k=1,2,3,4)$ obeys a white noise process, but allows contemporaneous correlation between the perturbed terms of the two equations. That is, changes in other factors can have simultaneous effects on multiple variables, which corresponds to the general economic sense.

$$
\operatorname{cov}\left(\varepsilon_{m p}, \varepsilon_{n q}\right)=\left\{\begin{array}{cl}
\sigma_{m n} & \text { if } p=q \\
0 & \text { if others }
\end{array},(m \neq n)\right.
$$

We use column vector to represent a contemporaneous variable and merge the corresponding coefficients into a matrix form. Then (2) can be simplified as (3), as is shown below:

$$
\left(\begin{array}{c}
H P_{t} \\
R_{t} \\
M_{t} \\
L P_{t}
\end{array}\right)=\Gamma_{0}+\sum \Gamma_{i}\left(\begin{array}{c}
H P_{t-i} \\
R_{t-i} \\
M_{t-i} \\
L P_{t-i}
\end{array}\right)+\left(\begin{array}{c}
\varepsilon_{1 t} \\
\varepsilon_{2 t} \\
\varepsilon_{3 t} \\
\varepsilon_{4 t}
\end{array}\right) .
$$

$\Gamma_{i}$ is the coefficient matrix of the model, $\quad i=(1,2,3, \cdots, n)$, as is shown in equation (4),

$$
\Gamma_{0}=\left(\begin{array}{l}
d_{1} \\
d_{2} \\
d_{3} \\
d_{4}
\end{array}\right), \quad \Gamma_{i}=\left(\begin{array}{llll}
\alpha_{1 i} & \beta_{1 i} & \gamma_{1 i} & \varepsilon_{1 i} \\
\alpha_{2 i} & \beta_{2 i} & \gamma_{2 i} & \varepsilon_{2 i} \\
\alpha_{3 i} & \beta_{3 i} & \gamma_{3 i} & \varepsilon_{3 i} \\
\alpha_{4 i} & \beta_{4 i} & \gamma_{4 i} & \varepsilon_{4 i}
\end{array}\right) .
$$

\section{Empirical Studies}

\subsection{Variable Selection and Data Source}

The data in this paper comes from the CSMAR database of CCER (China Center for Economic Research) and the website of China National Bureau of Statistics.

Before 1998, China implemented the public rental system. After the employment of staff of enterprises and public 
institutions, they can get houses from the Company at a lower price. There was not a complete real estate market in China at that time. In 1998, the State Council announced a complete cessation of the physical distribution of housing and turned to the monetizing housing distribution. The multi-level urban housing supply system based on the establishment and improvement of affordable housing was put forward for the first time. As a result, the pricing mechanism of the real estate market was gradually established and perfected. The early pricing mechanism of real estate market is faced with the process of "Double-track Model" restructuring, which is subject to a lot of policy interventions. As a result, real estate transaction prices do not truly reflect the supply and demand in the market. Therefore, the text set the sample interval from January 2005 to June 2017 in order to accurately analyzing the reasons for the rapid growth of real estate prices in China.

It is commonly believed that the main channel of influence between the real estate market and monetary policy is the market interest rate and credit scale. In order to further analyze whether land finance drives the real estate price, and figure out the impact on monetary policy, this article chooses the real estate price, the land price, the interest rate and the money supply as the analysis variables. The same as the real estate price data (real estate sales divided by real estate sales area); the turnover of land divided by the area of land transactions would be the land price variables that reflect the real estate land construction costs. The data of the transaction of real estate transactions volume and the transaction area are all from the CSMAR database. The interest rate is selected from the monthly weighted inter-bank interest rate announced by the National Bureau of Statistics of China. In the literature research, M2 is usually chosen to reflect the growth of the money supply. As a monetary indicator, M2 can better reflect the central bank's monetary policy adjustment information. Therefore, this paper selects M2 as the money supply index. There is a lack of January turnover and area of real estate transaction in the CCER database. Therefore, this paper uses backward prediction to make up.

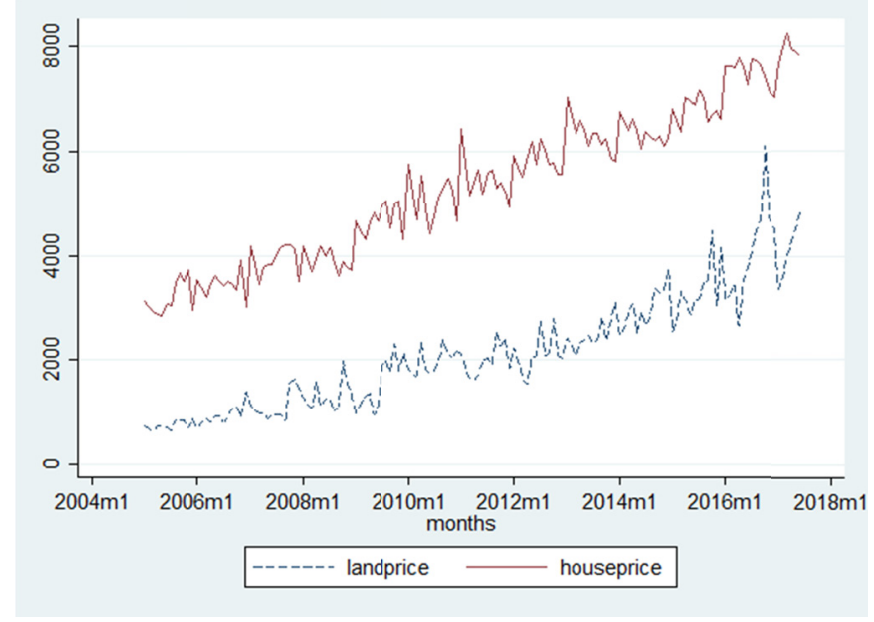

Figure 1. Real estate prices and land prices increasing trend

Source: the CSMAR database of CCER (China Center for Economic Research) and the China National Bureau of Statistics (http://www.stats.gov.cn).

Figure 1 shows the increase in China's real estate prices and land prices from 2005 to June 2017.After the implementation of housing system reform in 1998, the price of real estate has risen rapidly since 2003 after a short period of institutional adjustment. From 2000 to 2016, the sales of commercial residential buildings in China increased by 11.4055 trillion yuan, with an average annual increase of $26.99 \%$, while the GDP growth rate was only $9.42 \%$ over the same period.

In recent years, the rapid growth of real estate prices in China has aroused the widespread concern among domestic scholars. Zhou Bin and Du Liangsheng (2010) think that "land finance" is an intrinsic factor to push up real estate prices; the land prices have a significant impact on real estate prices. Government departments expand the scale of fiscal expenditure to stimulate economic development in order to seek better performance, but also give rise to large-scale fiscal deficits. In order to reduce the fiscal deficit, the government will sell land use rights, or increase land taxes and take other methods to raise financial resources. Lu Hongyou and his colleague (2011) found that between 2000 and 2009 , the revenue on the land of most local governments accounted for $60 \%$ of the total fiscal revenue each year. As a result, the increase in the price of land transactions is an important factor to promote the rapid growth of real estate prices. 


\subsection{Stationarity Test}

\subsubsection{Unit Root Test}

The vector autoregressive model requires that the data have stationarity. Therefore, before establishing the model, we need to conduct the stationarity test on the time-series data of real estate price, land price, interest rate, and money supply. We should eliminate the effect that the non-stationary sequence may have to the unit root and avoid the problem of "spurious regression". In this paper, we use Stata to conduct ADF unit root test on the original sequence of variables, the test is conducted at a significance level of $5 \%$ to figure out whether the four variables and satisfy the stationary hypothesis. The preliminary test results show that the original sequence of variables is non-stationary. Therefore, we regard the variable as a differential sequence and conduct the stationarity test again. The result is shown below:

Table $1 . \mathrm{ADF}$ test results $(H P, R, M, L P$, at $5 \%$ significance level)

\begin{tabular}{llll}
\hline variable & ADF statistics & P-value & Stationarity results \\
\hline$H P$ & -3.504 & 0.0079 & Stationary \\
$R$ & -3.466 & 0.0089 & Stationary \\
$M$ & -3.395 & 0.0111 & Stationary \\
$L P$ & -3.810 & 0.0028 & Stationary \\
\hline
\end{tabular}

It can be seen from Table 1 that at the significance level of 5\%, the ADF statistic corresponding to the differential sequence of, and is less than the critical value of -2.888 . Thus we refute the null hypothesis that the differential sequence of variables satisfies the stationarity assumption.

\subsubsection{The Stationarity Test of VAR System}

Before modeling a VAR model, a pre-modeling analysis is required.

First of all, we need to estimate the order of the VAR model first. We combined Stata's judging instruction with the information criterion, and the results show that the optimal lag order of FPE criterion and the AIC criterion is 5, while the statistics of HQIC criterion and SBIC criterion are 3 and 1. Based on the majority principle, this paper establishes the structural vector autoregressive model with a lag order 5 .

Second, in order to determine the validity of the impulse response analysis, it is necessary to determine whether all the eigenvalues are less than one before the impulse response analysis was conducted to variables. The test is conducted on the stationarity of the structural vector autoregressive model, and the result is shown below: All the eigenvalues are in the unit circle so that the VAR system is stationary.

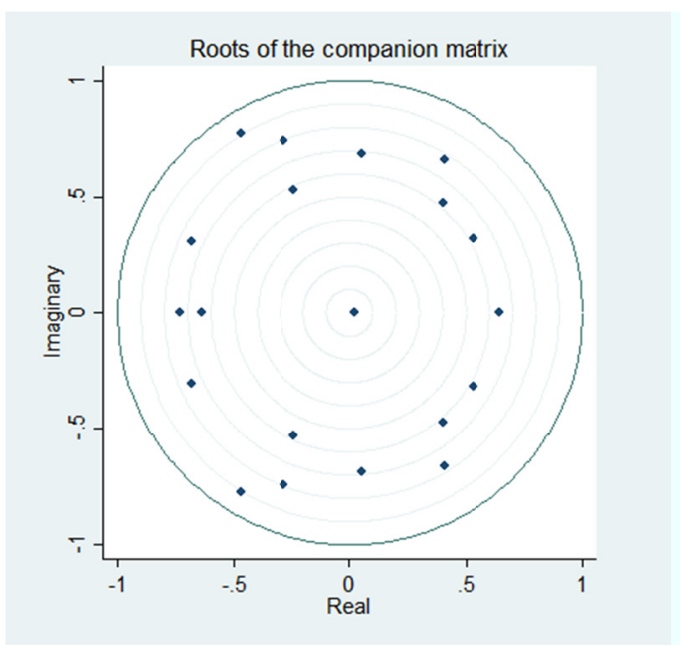

Figure 2. Result of VAR system stationarity test

Although all the eigenvalues of the VAR model fall within the unit circle, some points are closer to the boundary of the unit circle, indicating that the interaction between the variables selected in this paper is lasting. Moreover, there may be an endogenous relation that needs further analysis.

\subsection{The Order of Variables Interaction}

\subsubsection{Granger Causality Test}

After the VAR model has been established, it is necessary to determine the dynamic effect of the variables. In the analysis framework of vector autoregressive model, we consider the causation between variables and conduct Granger causality test on the variables. The results of Granger causality test is shown below: 
Table 2. Results of model variables Granger causality test (at 5\% significance level)

\begin{tabular}{lll}
\hline Original hypothesis & $\chi^{2}$ Statistics & P-value \\
\hline$R$ is not Granger cause of $H P$ & 5.7526 & 0.331 \\
$M$ is not the Granger cause of $H P$ & 3.7381 & 0.588 \\
$L P$ is not the Granger cause of $H P$ & 12.338 & 0.030 \\
$H P$ is not the Granger cause of $M$ & 7.651 & 0.177 \\
$R$ is not the Granger cause of $M$ & 29.476 & 0.000 \\
$L P$ is not the Granger cause of $M$ & 4.7601 & 0.446 \\
$H P$ is not the Granger cause of $R$ & 64.329 & 0.000 \\
$M$ is not the Granger cause of $R$ & 5.9742 & 0.309 \\
$L P$ is not the Granger cause of $R$ & 6.4643 & 0.264 \\
$H P$ is not the Granger cause of $L P$ & 2.4947 & 0.777 \\
$R$ is not the Granger cause of LP & 3.7999 & 0.579 \\
$M$ is not the Granger cause of LP & 3.8033 & 0.578 \\
\hline
\end{tabular}

It can be seen from that at a 5\% significance level, have a long-term effect to can be accepted; at a significance level of $1 \%$, can be considered as a Granger cause of, and is able to explain. According to the result of Granger causality test, the order of influence of variables is

$$
L P \Rightarrow H P \Rightarrow R \Rightarrow M \text {. }
$$

The order of the variables obtained by Granger causality test illustrates two important issues in China's real estate market. First, the development of China's real estate market is related to the revenue model of "land finance" adopted by the government to a certain extent. Rising real estate prices are driven by cost. The growth of land prices can explain the long-term growth of real estate prices. This result is in line with the results obtained by Bjornland and Jacobsen while analyzing the real estate data of the United Kingdom, Switzerland, and Norway in 2009; second, changes in the real estate market in China can affect the market interest rate and hence the money supply. This shows that the adjustment of interest rates and money supply variables takes the change of real estate prices as a reference, that is, when the People's Bank of China (PBC) is formulating monetary policy, it uses the real estate price as an intermediary target.

\subsubsection{Cross-Correlation Analysis Results}

The general view is that rising interest rates will increase the cost of real estate investment, which will prompt the real estate prices. However, according to the Granger causality test, the influence order between real estate prices and interest rates appears to be reversed. Real estate prices will affect the changes in interest rates and do not match the results of the theoretical analysis of cost. In order to further confirm the influence order of variables, we use Stata to draw out the cross-correlogram of $H P, R$ and $M$, as is shown in Figure 3:
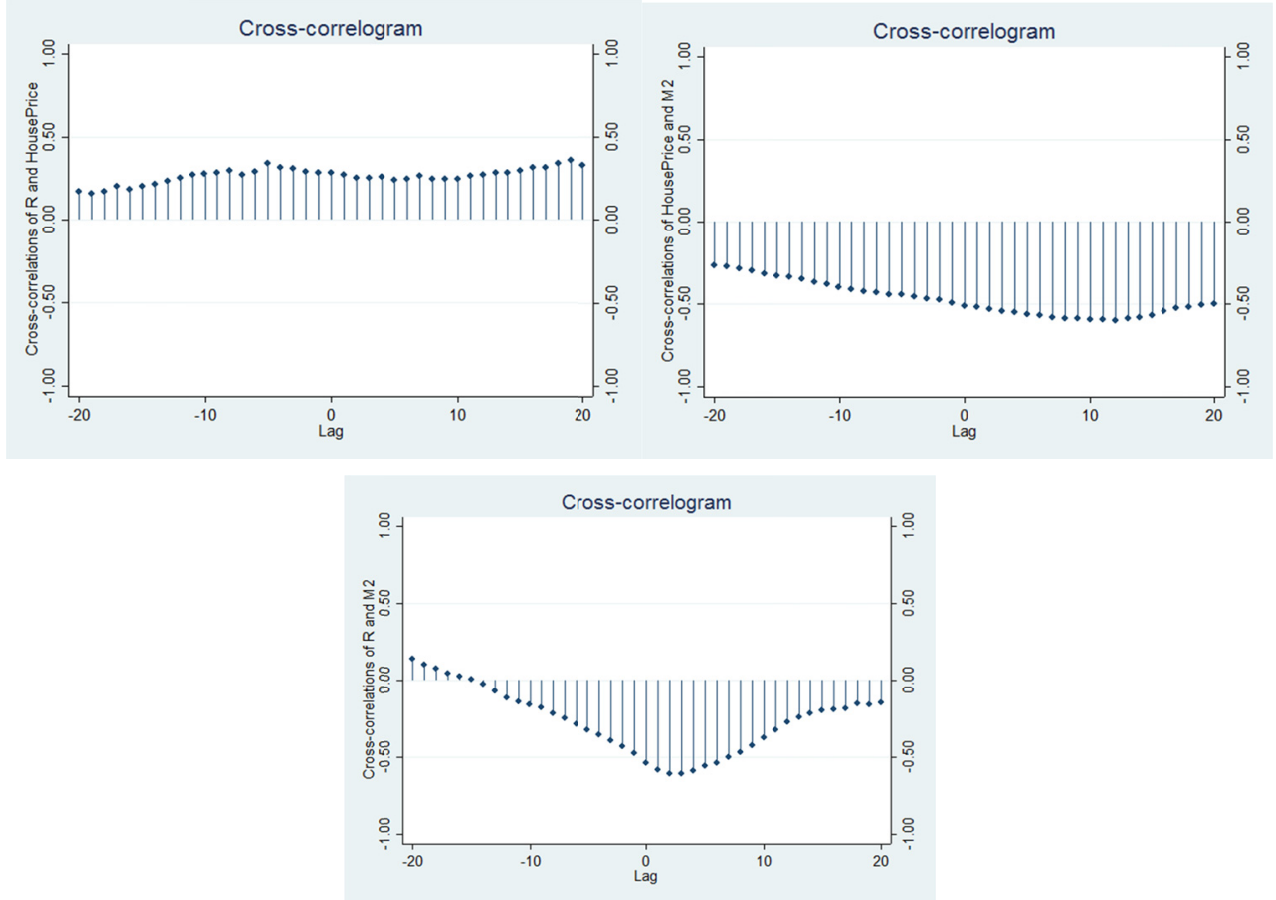

Figure 3. The cross-correlogram of $H P, R$ and $M$ 
It can be seen in Figure 3 that the lag phase of money supply affecting by the real estate prices is 12 months, and the impact period on interest rates is relatively short, only 5 months. The lag phase between interest rates and money supply is determined to be three months, which means that the change in interest rates has the highest correlation with the money supply level of three months lag.

The results of the cross-correlogram analysis show that the rise of the real estate market will affect the supply and demand of funds in the money market. The funds pursue profit freely and will tend toward the real estate market with higher returns, causing a structural imbalance in the supply of capital markets. Large amounts of capitals flow into the real estate market, leading to a rise in interest rates, which is consistent with the results of Granger causality test.

According to the empirical research, when the interest rate of capital market has a clear upward trend, the central bank will adopt a loose monetary policy to reduce the interest rate level so as to keep the interest rate of the domestic capital market stable. However, this will cause a large number of monetary funds to flow into the real estate market continuously, while the real economy sector is in short supply of funds. Lower investment will affect the economic output growth, and the continued loose monetary policy will make a lot of money into the real estate market. Rising real estate prices may give birth to the real estate bubble. If the real estate market price drops sharply, a large amount of capital will be released and give rise to the hyperinflation, which will affect the normal operation of the national economy.

\subsection{Structural Decomposition of VAR Model}

\subsubsection{Impulse Response Analysis}

According to the analysis above, we can see that the price of land is one of the factors that affect the real estate price. There is a further need to measure the magnitude of the impact of on, as well as the impact on causing the short-term changes in other variables. In this paper, we use the method of structural decomposition to quantitatively analyze the layoff effect to and led by the interaction among $H P, R$ and $M$. In this paper, we use the Stata software to set the maximum duration of variable effects to 20 months to plot the sequential pulse response diagram of $H P, R$ and $M$, and also to plot the results for impulse response graph that $H P$ corresponds to $L P$. As is shown below:

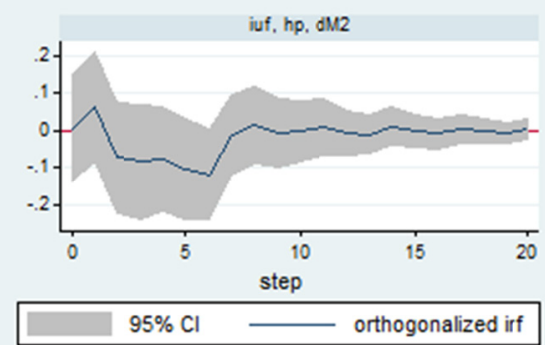

Graphs by irfname, impulse variable, and response variable

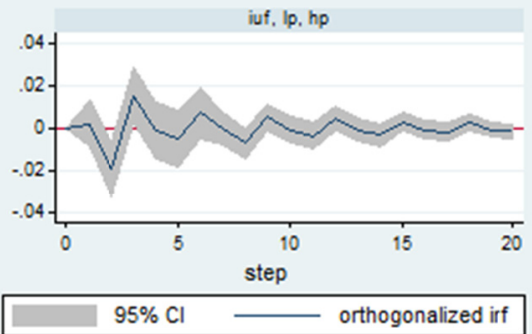

Graphs by irfname, impulse variable, and response variable

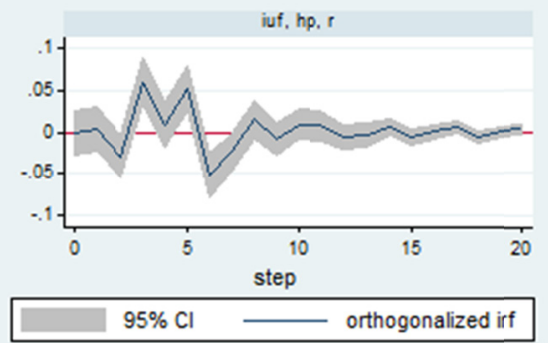

Graphs by irfname, impulse variable, and response variable

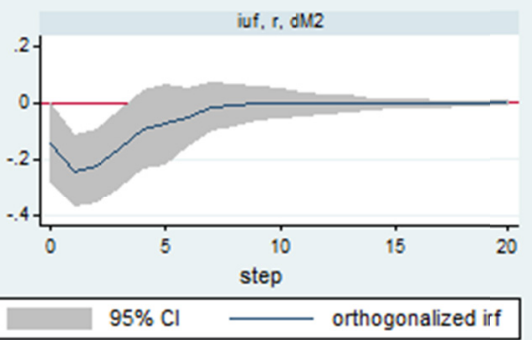

Graphs by irfname, impulse variable, and response variable

Figure 4. Impulse Response Analysis Results ( $i$ : Impulse Variables; $r$ : Response Variables)

The top left of the impulse response graph shows the money supply response to changes in real estate prices. Real estate prices will have an impact on the money supply, mainly by affecting the interest rate and making the central bank's monetary policy to passively adjust the money supply, in order to maintain a stable state of the capital market interest.

The upper right is the impulse response of the interest rate on the real estate price changes. It can be seen from the approximate shape of the response curve, after implementing the increments of real estate prices, the interest rate level changes positively at first, then reversely, and then continues to decline through multiple periods until it disappears. After the analysis, the explanation given in this paper is that the market interest rate is not only affected by the market 
supply and demand but also reflects the expected changes of some market participants. Interest rates are firstly affected by the supply and demand of funds. The insufficient supply of funds leads to the rise of interest rates. When the funds rise to a certain extent, the market is expected to lower interest rates in the future and investors will start to buy bond assets, thus lowering interest rates.

From the lower left of the impulse response graph can be found, the market interest rates have an impact with more intense fluctuations on the real estate price changes. The main reason is that the interest rate level in China's capital market is also used as an intermediate index of the central bank's monetary policy. The open market operations taken by the central bank affect the money supply level, and also vibrate the market interest rate levels. The open market operations make the observed interest rates change. At the same time, there are also policy-related factors. In addition to the policy factors, other factors also affect the market interest rate fluctuations, exacerbating the uncertain effect that the real estate market has on the interest rates.

As can be seen from the impulse response diagram at the lower right, the impact of interest rates on the money supply can better reflect the policy adjustment of the money supply. In a stable foreign exchange market, the target of money supply designated by the central bank is generally not influenced by other market factors and has relatively strong fixedness. Therefore, the impulse response of interest rates on the money supply is relatively smooth.

\subsubsection{Variance Decomposition of Prediction Error}

The results of Granger causality test and impulse response analysis show that land price has a positive effect on the real estate price, which is mainly reflected in the impulse response result of the land price to the real estate price. The frequent vibration of pulse curve shows that the land price, as an exogenous variable, certainly has an impact on real estate price, but it is only one of the cost components of real estate price. The impact on real estate price needs to be further measured. According to the investment cost theory, the rise in interest rates will also result in the growth of real estate prices. In order to further analyze the impact of other variables on. We can take variance decomposition methods to analyze the forecast error of real estate price, so as to analyze the contribution of each variable to the changes of.

We use Stata to draw the variance decomposition graph of forecast error of, as is shown in Figure 5,

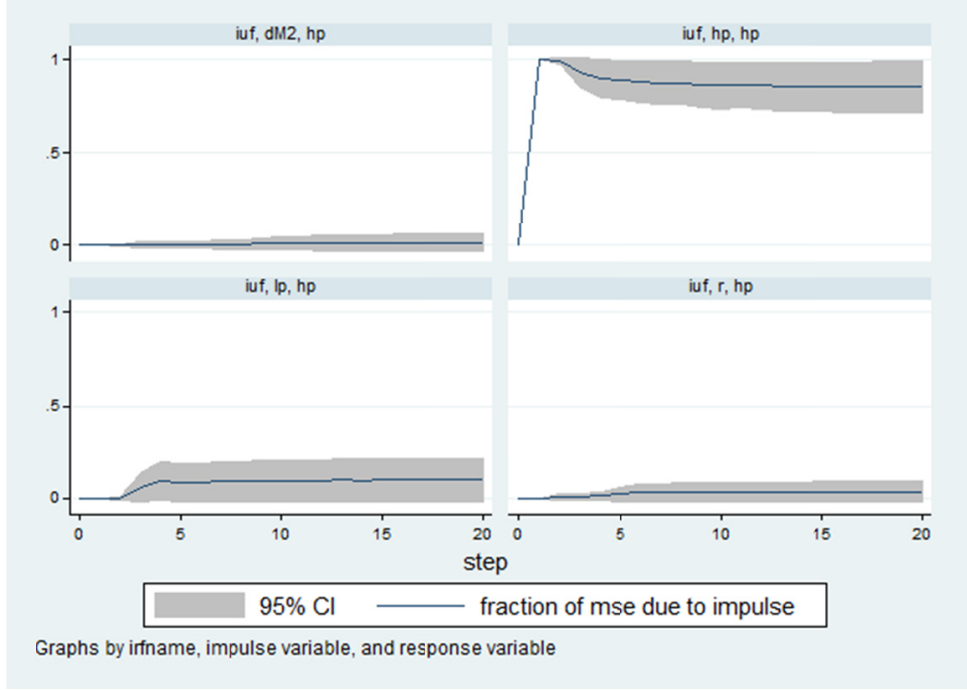

Figure 5. Variance Decomposition of Predictive Error

From the variance decomposition of forecast error of real estate prices, we can see that among the three variables, $L P, R$ and $M, L P$ has the largest impact on real estate prices. The change of real estate price is greatly affected by the change of land price, while the influence of interest rate level and money supply on real estate price is almost negligible. Among the explanatory variables of the real estate price increase, the growth of land price can reflect the driving force of house price rising to a certain extent, but the influence degree is relatively small. This shows that the land price is only one of the factors that affect the real estate price changes, and cannot fully explain the fact that China's real estate prices have risen more than 10 years.

\section{Conclusions and Recommendations for New Policy}

\subsection{Conclusion}

In this paper, VAR model is used to conduct an empirical study on the price transmission mechanism of monetary policy and real estate market, and the factors that promote the real estate price to rise year by year are analyzed. The results show that, 
(1) "Land Finance" is an important factor in promoting the real estate price increase. Since the implementation of housing system reform in China in 1998, real estate prices have been gradually monetized. Real estate prices have been rising year by year since the price transition. Rising land prices are the main factor driving housing prices upward.

(2) The effect of the policy effect of monetary policy will be affected by changes in real estate prices. Monetary policy reduces capital market interest, helping to reduce real estate prices to a certain extent. However, a large amount of capital will flow into the real estate industry because of this, resulting in a decrease in the scale of industrial investment and thus affecting the economic development in other industries. Land finance will increase real estate prices while stimulating the economy, having a reverse impact on the development of real estate industry.

(3) China's regulation of the real estate market is lagging behind. When the real estate price changes cause deviation from the expected level of the intermediate index of monetary, the Central Bank is forced to adopt the means of adjusting monetary policy, which increases the uncertainty of monetary policy. The People's Bank of China adopted a passive monetary policy to regulate real estate prices indirectly.

\subsection{Suggestion on Policy}

(1) Adjust government revenue structure to curb land costs and push up real estate prices

In order to avoid excessive passive money supply growth, we need to start from the real estate industry, limit the abnormal rise in real estate prices, and block the impact of real estate prices on the capital market interest. What needs to be considered is that the current real estate market of China has absorbed a large amount of funds. If we restrict the real estate prices compulsively, it will result in a drop in real estate prices and the release of previously saved funds. That will lead to a substantial increase in the supply of funds in the market, which may give rise to the vicious inflation. Therefore, on the one hand, it is necessary for the government to adjust its fiscal revenue structure, and to avoid the implementation of land finance to raise funds. The government should also reduce the cost of land construction in the real estate industry. On the other hand, the government needs to implement a positive monetary policy to adjust the capital market interest so that the real estate price will slowly decline.

In terms of local governments, it will help control the real estate prices by improving the government revenue and expenditure structure, dividing the fiscal revenues of the central and local governments in a reasonable manner, and reducing the proportion of land tax and land prices of local governments.

The main harms brought by "Land Finance" include, firstly, the scale of rise of real estate price is too large, overdrawing the potential of future economic development (which will do harm to economic development mainly through the occupation of industrial investment); Second, it is easy to form a real estate bubble. Once the bubble burst, it will have a huge impact on the economy as a whole. Thirdly, excessive house prices do not match the growth of people's income and reduce people's living standards.

(2) Adjust the monetary policy intermediary target and reduce the passiveness of monetary policy

For the principle of monetary policy initiative, the central bank should strengthen the control of monetary policy. The passive adjustment of monetary policy triggered by rising real estate prices is not conducive to the PBC taking the monetary policy measures to implement the macro-control objectives. The financial market in our country is not yet perfect, leading to the inefficiency of monetary policy. With reference to the precedents of other developed countries, more and more effective intermediate target of monetary policy should be adopted. The monetary policy intermediary target of the central bank is adjusted to the interest rate by the money supply, which can adjust to the interest rate fluctuation caused by the real estate price in time. The central bank should keep an eye on real estate prices or adjust its policy objectives in light of changes in real estate prices to maintain the initiative of monetary policy and enhance the effect of monetary policy.

\section{References}

Bernanke, B. S., \& Gertler, M. (1995). Inside the black box: the credit channel of monetary policy transmission (No. w5146). https://doi.org/10.3386/w5146

Bernanke, B., \& Gertler, M. (2000). Monetary policy and asset price volatility (No. w7559). National Bureau of economic research. https://doi.org/10.3386/w7559

Bjørnland, H. C., \& Jacobsen, D. H. (2010). The role of house prices in the monetary policy transmission mechanism in small open economies. Journal of financial stability, 6(4), 218-229. https://doi.org/10.1016/j.jfs.2010.02.001

Brischetto, A., \& Voss, G. (1999). A structural vector autoregression model of monetary policy in Australia. Economic Research Department, Reserve Bank of Australia.

Cao, G., Feng, C., \& Tao, R. (2008). Local "land finance" in China's urban expansion: challenges and solutions. China \& World Economy, 16(2), 19-30. https://doi.org/10.1111/j.1749-124X.2008.00104.x 
Chen, S., \& Wang, X. (2016). Financing Costs, Real Estate Price Fluctuation and Monetary Policy Transmission. Financial Research, (3), 1-14.

Guofu, C., \& Zhiqiong, Q. (2009). China Land Finance under the Financial Illusion from the Perspective of Law and Economics [J]. Nankai Journal (Philosophy, Literature, and Social Science Edition), 1, 013.

Kwon, E. (1998). Monetary policy, land prices, and collateral effects on economic fluctuations: evidence from Japan. Journal of the Japanese and International Economies, 12(3), 175-203. https://doi.org/10.1006/jjie.1998.0400

Mueller, G., \& Pauley, K. (1995). The effect of interest-rate movements on real estate investment trusts. Journal of Real Estate Research, 10(3), 319-325.

Phillips, P. C. (1995). Fully modified least squares and vector autoregression. Econometrica: Journal of the Econometric Society, 1023-1078. https://doi.org/10.2307/2171721

Phillips, P. C. B., \& Toda, H. Y. (1994). Vector autoregression and causality: a theoretical overview and simulation study. Econometric Reviews, 13(2), 259-285. https://doi.org/10.1080/07474939408800286

Poterba, J. M., Weil, D. N., \& Shiller, R. (1991). House price dynamics: the role of tax policy and demography. Brookings Papers on Economic Activity, 1991(2), 143-203. https://doi.org/10.2307/2534591

Quigley, J. M. (1995). A simple hybrid model for estimating real estate price indexes. Journal of Housing Economics, 4(1), 1-12. https://doi.org/10.1006/jhec.1995.1001

Qun, W., Yongle, L., \& Siqi, Y. (2015). The incentives of China's urban land finance. Land Use Policy, 42, 432-442. https://doi.org/10.1016/j.landusepol.2014.08.015

Sbordone, A. M. (2002). Prices and unit labor costs: a new test of price stickiness. Journal of Monetary Economics, 49(2), 265-292. https://doi.org/10.1016/S0304-3932(01)00111-8

Schwartz, A. J. (2003). Asset price inflation and monetary policy. Atlantic Economic Journal, 31(1), 1-14. https://doi.org/10.1007/BF02298459

Sims, C. A. (1986). Are forecasting models usable for policy analysis?. Quarterly Review, (Win), 2-16.

Thakor, A. V. (1996). Capital requirements, monetary policy, and aggregate bank lending: theory and empirical evidence. The Journal of Finance, 51(1), 279-324. https://doi.org/10.1111/j.1540-6261.1996.tb05210.x

Wang, J., Lv, C., \& Dai, S. (2008). Land Finance and Real Estate Development. Local Finance Research, (10), 14-17.

Weise, C. L. (1999). The asymmetric effects of monetary policy: A nonlinear vector autoregression approach. Journal of Money, Credit and Banking, 85-108. https://doi.org/10.2307/2601141

Xu, X. E., \& Chen, T. (2012). The effect of monetary policy on real estate price growth in China. Pacific-Basin Finance Journal, 20(1), 62-77. https://doi.org/10.1016/j.pacfin.2011.08.001

Yi, G., \& Wang, Z. (2002). Monetary Policy and Financial Asset Prices. Economic Research, 3(1), 121.

Zhai, Q. (2001). Asset Prices and Monetary Policy. Economic Research, 7, 60-67.

Zhou, B., \& Du, L. (2010). "Land Finance" and real estate prices: a theoretical analysis and empirical research. Finance and Trade Economics, (8), 109-116.

\section{Copyrights}

Copyright for this article is retained by the author(s), with first publication rights granted to the journal.

This is an open-access article distributed under the terms and conditions of the Creative Commons Attribution license which permits unrestricted use, distribution, and reproduction in any medium, provided the original work is properly cited. 